\author{
Є.Г. Опанасюк, к.т.н., доц. \\ Д.Б. Бегерський, к.т.н., доц. \\ М.М. Можаровський, ст. викладач \\ І.В. Вітюк, ст. викладач \\ Державний університет «Житомирська політехніка»
}

\title{
Дослідження транспортного акустичного забруднення і факторів його залежності на прикладі перехресть магістральних вулиць міста Житомира
}

\begin{abstract}
Шум від автомобільного транспорту - иее найбільш розповсюджений вид несприятливого екологічного впливу на організм людини. Аналіз результатів відомих досліджень свідчить про те, щуо джерелами 60-80 \% акустичного забруднення міст є рух транспортних засобів. Від шкідлиого впливу автомобільного шуму страждають люди, які проживають або працюють поблизу магістральних вулиць. Він суттєво залежить від інтенсивності транспортного потоку, типів транспортних засобів, їх швидкості та технічного стану $і$ значно зростає під час так званих годин «пік», коли рух транспортних засобів стає найбільш інтенсивним. Також рівень иуму може бути завищений внаслідок малої насиченості або повної відсутності зелених насаджень вздовж доріг, близькості від дороги будівель та їх зовнішнього покриття з низькою поглинаючою здатністю, відсутністю незабудованих зон та ін. Крім зазначених факторів, особлива увага в роботі приділена акустичному забрудненню територій, щьо безпосередньо прилягають до перехресть, оскільки там присутні додаткові фактори впливу на рівень шуму (збільшення концентрації транспортних засобів, додатковий шум при спрацюванні гальм, робота двигунів на перехідних режимах та ін.).
\end{abstract}

Ключові слова: транспортні засоби; перехрестя; рівень шуму; акустичне забруднення.

Актуальність теми. На сьогоднішній день шумове забруднення стало одним із найнесприятливіших факторів шкідливого впливу на здоров'я людини і на стан природного середовища в містах. Шумове забруднення шкідливо впливає на здоров'я людини і ії працездатність, діючи на органи слуху при цьому викликаючи різні слухові, серцево-судинні захворювання. Актуальність цієї роботи полягає у виявленні причин та визначенні методів щодо зниження цієї проблеми.

Аналіз останніх досліджень та публікацій, на які спираються автори. Зокрема аспектам захисту населення від негативного впливу акустичного забруднення присвячено публікації О.М. Величка [1], В.П. Кучерявого [2], І.П. Білокура [3], М.Пукало, А.Наконечного та К.Ідрісова [4], Л.О. Коваленка [5], Ф. Стольберга [6], Л.В. Янковської [7] та ін. Загальнодержавна важливість цієї проблеми підтверджується вимогами Закону України «Про забезпечення санітарного та епідемічного благополуччя населення» [8]. Наслідки негативного впливу акустичного забруднення висвітлені в роботах Залеського I.I. та ін. [9].

Метою статті $є$ визначення і подальше вивчення причин акустичного забруднення магістральних вулиць міста Житомира 3 подальшим визначенням заходів технологічного і організаційного впливу, спрямованого на зниження шумового забруднення на перехрестях і ділянках доріг, що прилягають до них.

Викладення основного матеріалу. Місто Житомир - обласний центр Житомирської області, розташований на північному заході України на площі 60,83 кв. км з населенням 264 тис. осіб (2020р.), має змішане радіально-кільцеве розташування дорожньої мережі. У Житомирі зареєстровано і експлуатується понад 30 тисяч автомобілів різних марок і типів, міський комунальний пасажирський транспорт - це близько 200 тролейбусів, трамваїв і автобусів. Магістральними радіальними вулицями Житомира, на яких рух різних транспортних засобів найбільш інтенсивний, є вулиці, які починаються безпосередньо від майдану Соборного (центральний майдан Житомира) або безпосередньо біля нього, це вулиці: Київська, Покровська, Перемоги, Чуднівська (Черняховського), Грушевського та Велика Бердичівська. Значна інтенсивність руху, особливо в години «пік» (з 7 до 10, та 316 до 19 год), негативно впливає на рівень акустичного забруднення навколишнього середовища і викликає необхідність його постійного моніторингу. Ця проблема суттєво ускладнюється зі зростанням парку автомобілів у місті при майже незмінній дорожній мережі і є характерною для більшості міст України.

Подібне планування дорожньої мережі притаманне для більшості міст України, заснованих у XIII XIV століттях 3 населенням 250-350 тис. мешканців (Вінниця, Полтава, Луцьк, Рівне, Чернігів та ін.). Враховуючи близькість рівнів розвитку економіки названих регіонів і добробуту їх мешканців, можна стверджувати і про близькість структури типажу транспорту та забезпеченості населення автомобілями, а значить і проблем, пов'язаних з акустичним забрудненням цих міст.

(C) Є.Г. Опанасюк, Д.Б. Бегерський, М.М. Можаровський, І.В. Вітюк, 2021 
Поряд 3 негативними чинниками радіаційного, хімічного забруднення повітря і території міст акустичне забруднення стало одним із самим найнесприятливіших факторів шкідливого впливу на здоров'я людини. Населення міста практично постійно перебуває в зоні дії широкого за частотою i силою шуму, і адаптуватися до нього неможливо. Збільшення акустичного навантаження негативно впливає на здоров’я людини та іiі працездатність, діючи на органи слуху і при цьому викликаючи різні слухові, серцево-судинні захворювання.

Відомо, що автомобільний транспорт у населених пунктах є одним із головних джерел негативного впливу на екологічний стан навколишнього середовища і здоров'я людини. При цьому вважається, що основний збиток навколишньому середовищу від автотранспорту завдається внаслідок викидів токсичних складових відпрацьованих газів, а такому фактору, як шум, належної уваги не приділяється, та і його вплив на організм людини ще до кінця не вивчено. Шум з рівнем 50-60 дБА створює відчутне навантаження на нервову систему, особливо якщо людина займається розумовою діяльністю. Шум 3 рівнем вище 70 дБА викликає фізіологічний вплив, а при 85-90 дБА може призвести до погіршення слуху. Водночас частка шумового забруднення території міст (до 80 \%) обумовлена саме впливом автотранспортних потоків.

Як відомо, середні величини інтенсивності зовнішнього шуму орієнтовно становлять:

- $\quad$ легкові автомобілі - $70 \div 80$ дБА;

- $\quad$ автобуси $-80 \div 85$ дБА;

- $\quad$ вантажні автомобілі - $85 \div 95$ дБА;

- $\quad$ мотоцикли - $85 \div 100$ дБА;

- $\quad$ трамваї - $75 \div 95$ дБА.

Рівень і характеристики шуму суттєво залежать від типу двигуна, технічного стану автомобіля, режиму й швидкості руху, ступеня завантаження автомобіля, інтенсивності руху тощо.

До перелічених вище вулиць переважно прилягають житлові будинки, торговельні, розважальні, медичні і навчальні заклади та ін. Державні санітарні правила планування і забудови населених пунктів встановлюють допустимі рівні звуку на території житлової забудови (характеристикою джерел 3 непостійними акустичними характеристиками (транспорту та ін.) є еквівалентні та максимальні рівні звуку вказані в таблиці 1 [10].

Таблиияя 1

Еквівалентні та максимальні рівні звуку

\begin{tabular}{|c|c|c|c|}
\hline \multirow[t]{2}{*}{ Вид територій } & \multicolumn{2}{|c|}{$\begin{array}{l}\text { Допустимі рівні звуку } \\
\text { (дБА) }\end{array}$} & \multirow{2}{*}{$\begin{array}{c}\text { Час } \\
\text { доби }\end{array}$} \\
\hline & LA екв. & LA макс. & \\
\hline \multirow{2}{*}{$\begin{array}{l}\text { Території, що безпосередньо прилягають до будівель лікарень, } \\
\text { санаторіїв }\end{array}$} & 45 & 60 & День \\
\hline & 35 & 50 & Ніч \\
\hline \multirow{2}{*}{$\begin{array}{l}\text { Tериторії, що безпосередньо прилягають до житлових будинків, } \\
\text { будівель поліклінік, амбулаторій, будинків відпочинку, } \\
\text { пансіонатів, будинків-інтернатів, дитячих дошкільних закладів, } \\
\text { шкіл та інших навчальних закладів, бібліотек }\end{array}$} & 55 & 70 & День \\
\hline & 45 & 60 & Ніч \\
\hline \multirow{2}{*}{ Території, що прилягають до будівель готелей та гуртожитків } & 60 & 75 & День \\
\hline & 50 & 65 & Нiч \\
\hline Майданчики відпочинку на території лікарень та санаторіїв & 35 & 50 & День \\
\hline $\begin{array}{l}\text { Майданчики відпочинку на території мікрорайонів, груп житлових } \\
\text { будинків, будинків відпочинку, пансіонатів, майданчиків дитячих } \\
\text { дошкільних закладів, шкіл та інших учбових закладів, будинків- } \\
\text { інтернатів }\end{array}$ & 45 & 60 & День \\
\hline
\end{tabular}

Як і всі українські міста, Житомир не є виключенням щодо цієї екологічної проблеми, викликаної шумовим забрудненням. Найбільший рівень шуму в місті на магістральних вулицях спричинений автотранспортом, чисельний склад якого невпинно зростає впродовж останніх двадцяти - двадцяти п'яти років. Проблема акустичного забруднення міста постійно знаходиться в зоні уваги органів, що здійснюють контроль за дотриманням санітарних норм. У 2019 році фахівцями було проведено 218 вимірів акустичного забруднення та виявлено перевищення рівня шуму в 16 точках, що становить 7,3\% від загальної кількості проведених вимірів [35]. Вимірювання проводилося на території дитячих садочків, шкіл, лікувально-профілактичних закладів, закладів соціального забезпечення та на автомагістралях $\mathrm{i}$ перехрестях вулиць [11].

Також на рівень шуму було перевірено житлову зону Житомира, та за 12 адресами виявили перевищення еквівалентних і допустимих шумів. Найвищий рівень дБА (акустичних децибелів) виявився за адресою: проспект Миру, 2 (78 дБА при максимально допустимих 70 дБА), та за трьома іншими 
адресами, такими як: Бориса Тена, 62, Київська, 50 та Покровська 2/19 - 76 дБА. Наведені дані свідчать про необхідність постійного моніторингу акустичного забруднення в Житомирі і зокрема на міських дорогах та їх перехрестях. Проведення контролю акустичного забруднення підтверджується також результатами досліджень, проведених у Львові [12], Черкасах [13].

У цій роботі наведено результати дослідження шумового забруднення на перехрестях вул. Велика Бердичівська міста Житомира. Заміри проводилися на вул. Велика Бердичівська та вулицях, що іiі перетинають: Театральній, Старому Бульварі - Івана Кочерги, Івана Франка, Коцюбинського, Шевченка, Довженка, Гагаріна, Жуйка - Льва Толстого. Заміри проводилися за допомогою шумомірів Digital Sound Level Meter (рис. 1) при їх встановленні на відстані 1 м від проїзної частини вул. Великої Бердичівської та поперечних вулиць.

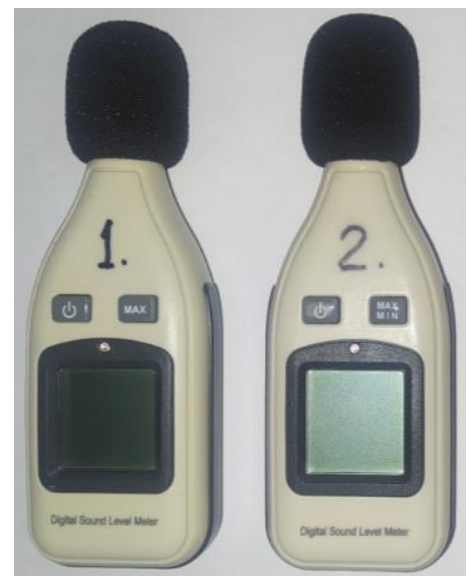

Puc. 1. Шумоміри Digital Sound Level Meter

Шумоміри Digital Sound Level Meter (рік випуску 2019) мають такі характеристики: діапазон вимірювання: 30-130 дБ; точність: $\pm 1,5$ дБ; роздільна здатність цифр: 4 цифри 0,1 дБ; частотна характеристика: 31,4 Гц - 8,5 КГц; швидкість відбору проб: 2 рази/с; автоматичний дисплей 3 підсвічуванням; індикація низького рівня заряду; автоматичне вимкнення живлення; живлення від акумулятора 9 v. Заміри проведено одночасно з обох сторін дороги під час ввімкнутого зеленого сигналу світлофора. Так на кожній ділянці перехрестя (наприклад, вулиць Великої Бердичівської і Театральної), тобто в 4 місцях (рис. 2), робили по 3 заміри. Цифрами 1-1 та 2-2 позначено місця замірів, які проводилися по вулиці Велика Бердичівська, 3-3 та 4-4 - відповідно на поперечних вулицях. Заміри проводилися одночасно в точках, позначених однаковими цифрами. За результатами 3-х замірів визначено середній показник рівня шуму.

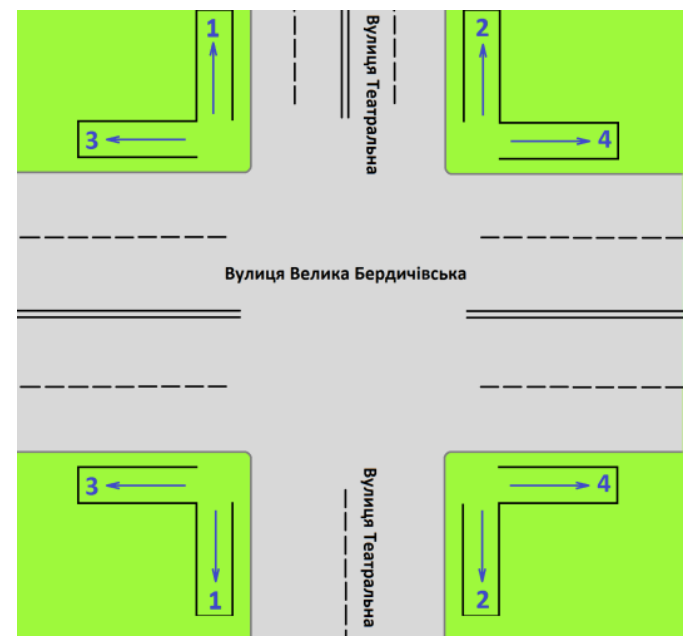

Рис. 2. Схема проведення замірів та напрямки розповсюдження звукових хвиль від джерела шуму

Розглянемо особливості планування, забудови, результати вимірювань акустичного забруднення перехресть вул. Велика Бердичівська та його аналіз.

На рисунку 3, а представлено схему та загальний вигляд споруд, що прилягають до перехрестя вулиць Велика Бердичівська - Театральна, а на рисунку 3, $\sigma$ - результати вимірювань рівня шуму в дБ залежно від відстані від проїзної частини. 

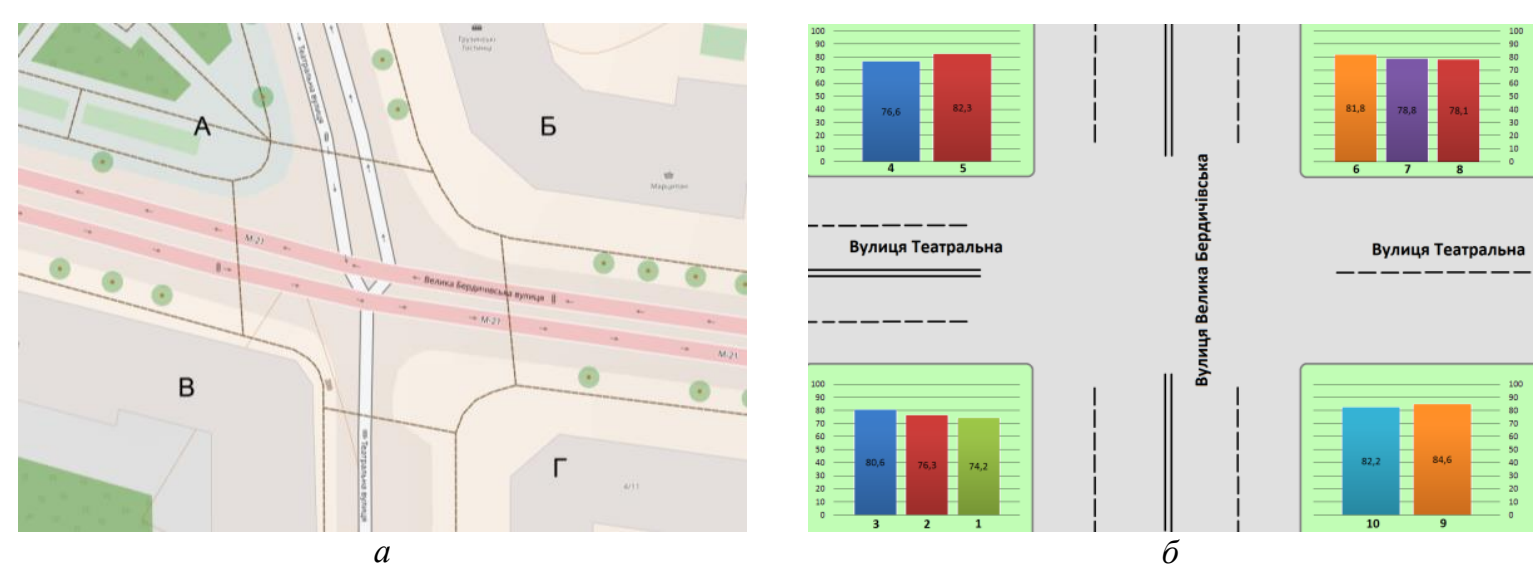

Рис. 3. Перехрестя вул. Велика Бердичівська - Театральна

На цьому перехресті рух вантажних автомобілів заборонено, дозволяється тільки рух міського та транспорту категорії В. На перехресті (рис. $3, \sigma$, зони А, В) за даними вимірювань середній показник рівня шуму сягає 82,2 дБ. На ділянці А (рис. $3, a$ ) простір відкритий для розсіювання звукових хвиль, а також на цій ділянці на шляху розповсюдження звукової хвилі є зелені насадження, які володіють властивістю розсіювання і послаблення звукових хвиль. Ділянка В (рис. 3, a) через інтенсивний потік транспортних засобів і при ширині тротуару між будівлею навчального закладу та проїзною частиною менш ніж 3,5 м також знаходиться в несприятливій зоні (80,6 дБ). Найвищий рівень шуму на ділянці Г (рис. 3, a), причиною чого $€$ висока інтенсивність транспортного потоку і наявність паркувального місця біля перехрестя, а також невеликий вільний простір, що розсіює звукові хвилі на цій ділянці перехрестя та відсутні зелені насадження - 84,9 дБ.

Нижчий показник на перехресті зафіксовано на ділянці Б (рис. 3, а) внаслідок більшої, ніж на ділянках В та Г відстані до будівлі. Рівень шуму суттєво змінюється залежно від категорії транспортного засобу, типу двигуна, технічного стану автомобіля, режиму й швидкості руху, ступеня завантаженості автомобіля, інтенсивності руху тощо. Дослідження шумового забруднення на цьому перехресті визначені за наявності потоку транспортних засобів на перехресті, зазначеному на рисунку 4.

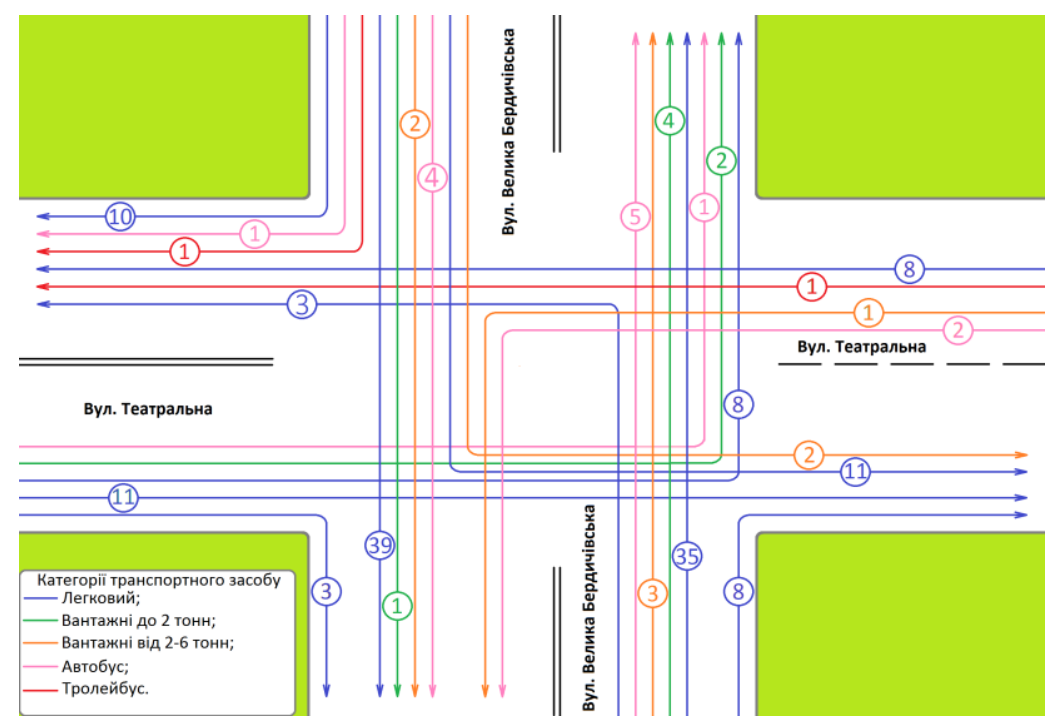

Рис. 4. Схема потоку транспортних засобів на перехресті вул. Велика Бердичівська - Театральна

На рисунку 5 представлено схему та загальний вигляд споруд, що прилягають до перехрестя вулиць Велика Бердичівська - Михайлівська. 


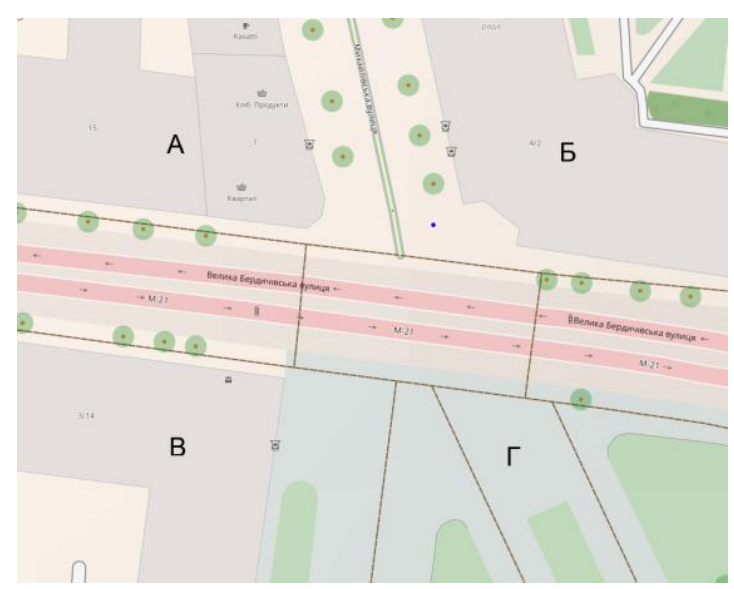

Рис. 5. Схема і загальний вигляд перехрестя вул. Велика Бердичівська-Михайлівська

На цьому перехресті рух транспортних засобів по вулиці Михайлівській заборонено, вздовж вулиці Великої Бердичівської заборонено рух всіх вантажних автомобілів, дозволено рух міського та транспорту категорії В. До перехрестя прилягають обласні та міські адміністративні організації, житлові будинки, будівлі мають скляні вікна, а також скляні двері та зовнішню поверхню без покриття звукопоглинаючими матеріалами, що надає можливість відбиття звукових хвиль із більшим коефіцієнтом, мінімальна кількість зелених насаджень, що не забезпечує поглинання і розсіювання шуму на ділянках А, Б, В, який у результаті в середньому становить 84,4 дБ. На ділянці Г цього перехрестя шум в середньому сягає 86,4 дБ, що є найбільшим на цьому перехресті.

На рисунку 6 показано схему та загальний вигляд споруд, що прилягають до перехрестя вулиць Івана Кочерги - Велика Бердичівська - Старий бульвар.

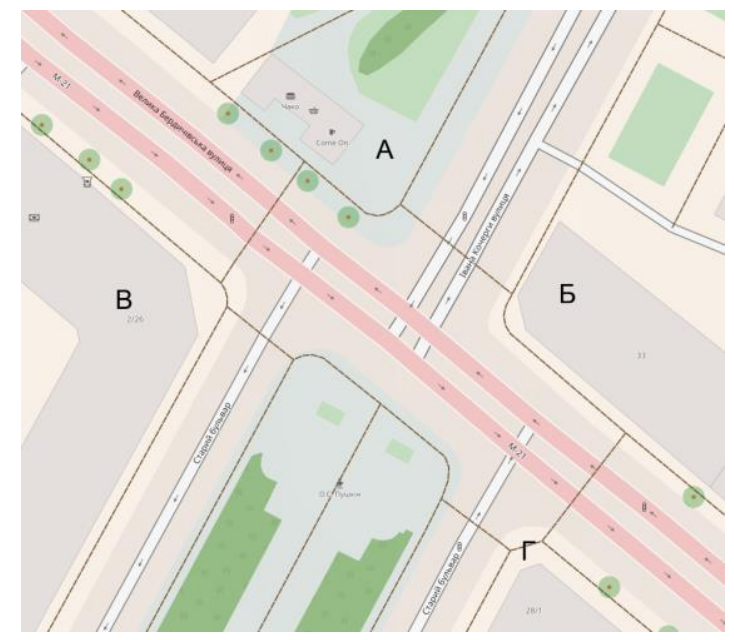

Рис. 6. Схема і загальний вигляд перехрестя вул. Івана Кочерги - Велика Бердичівська - Старий бульвар

На вулицях, що прилягають до перехрестя вул. Івана Кочерги - Велика Бердичівська Старий бульвар рух вантажних автомобілів заборонено. На ділянці А (рис. 6) шум сягає 83,8 дБ. Причиною цього є прилягання міської транспортної зупинки та торговельної точки, а також відбивання від сусідніх будівель звукових хвиль, які накладаються одні на інших, посилюючи звуковий фон.

На ділянці В (рис. 6) рівень шуму вищий, ніж на попередній через безпосередню близькість стін будівлі та відсутність зелених насаджень на цій ділянці перехрестя.

Найвищий показник зафіксовано на ділянці Б (рис. 6) внаслідок прилягання будівлі досить близько до проїзної частини, а отже до джерел шуму. В цьому разі звукові хвилі досить швидко надходять до стін будівель, відбиваючись від них без суттєвих втрат своєї енергії, оскільки будівля має скляні вікна, тверду зовнішню поверхню, що є фактором сприяння відбиванню звукових хвиль від цих поверхонь. Показник шуму на цій ділянці сягає 89,6 дБ.

Найнижчий рівень шуму зафіксовано на ділянці Г, що прилягає до цього перехрестя - 81,3 дБ, що пояснюється приляганням незабудованої зони відпочинку, яка сприяє розсіюванню звукових хвиль. 
На рисунку 7 представлено схему та загальний вигляд споруд, що прилягають до перехрестя вулиць Велика Бердичівська - Івана Франка.

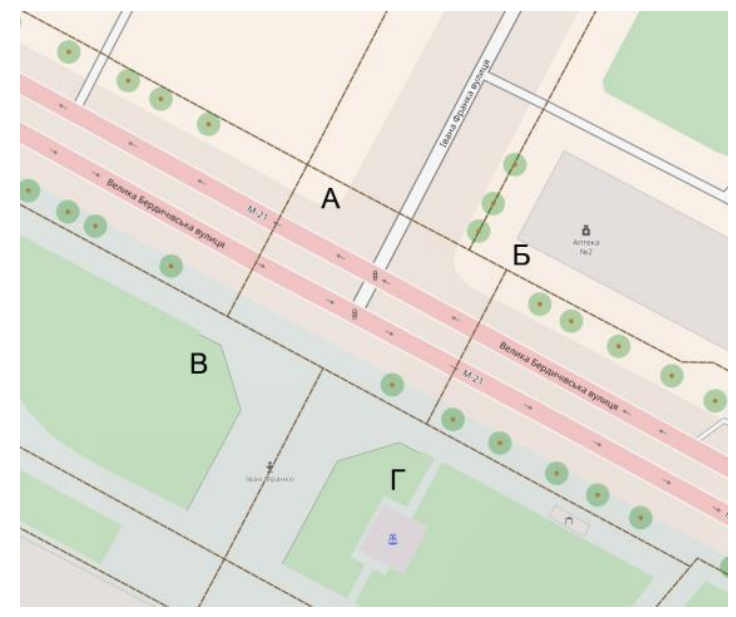

Рис. 7. Перехрестя вул. Велика Бердичівська - Івана Франка

Середне значення показників шуму на цьому перехресті становить 81,8 дБ. Найвищі показники на перехресті були зафіксовані в зонах Б і Г (рис. 7), причиною чого $\epsilon$ те, що на ділянці Б житловий будинок прилягає ближче до проїзної частини, тому звукові хвилі відбиваються від твердої поверхні будівлі, цим самим підсилюючи шумовий фон, а от на ділянці Г зосереджений інтенсивний рух транспортних засобів. До цієї ділянки прилягає зупинка маршрутних транспортних засобів, що під час їх рушання 3 місця посилює шум, чому сприяє близьке розташування стін будівлі. Найнижчі показники були зафіксовані на ділянках А, Г. Причиною цього $є$ наявність відкритого простору, відсутність поблизу будівель чи інших споруд. Зелені насадження також сприяють зменшенню рівня шуму.

На рисунку 8 представлено схему та загальний вигляд споруд, що прилягають до перехрестя вулиць Велика Бердичівська - Коцюбинського.

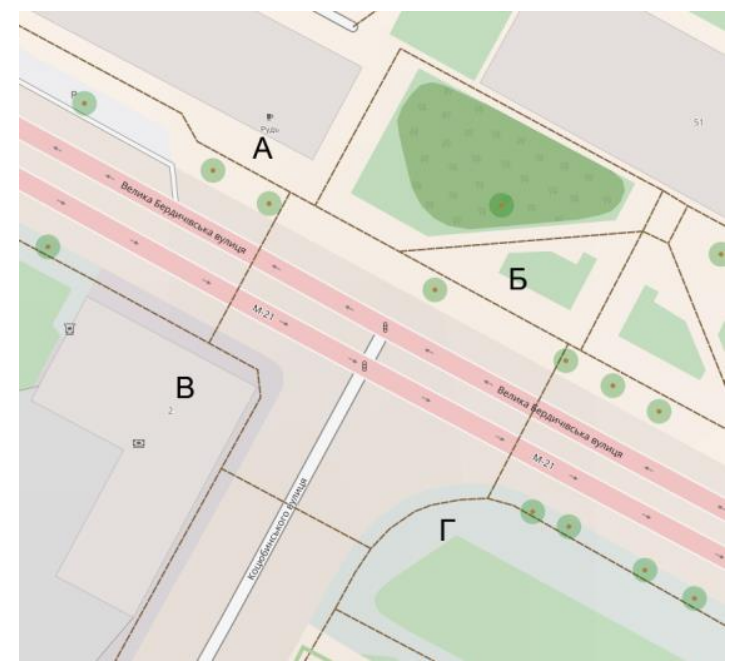

Рис. 8. Перехрестя вул. Велика Бердичівська - Кочүюбинського

На вказаному перехресті середній рівень шумності становить 82,8 дБ. На ділянках А, Б (рис. 8) рівень шуму сягає 83,4 дБ, причиною цього є прилягання будівлі ліворуч, крім того, відбивання звуку від сусідньої будівлі підсилює звуковий фон.

На ділянці В розташована адміністративна будівля, яка має скляні двері та вікна. Шумність на цій ділянці в середньому становить 84,5 дБ.

На ділянці Г найнижче значення середнього показника, який становить 79,8 дБ, внаслідок наявності можливості розсіювання звукових хвиль на вільному від забудови просторі.

На дорогах,що прилягають до цього перехрестя, рух вантажних автомобілів заборонено. 
На рисунку 9 представлено схему та загальний вигляд споруд, що прилягають до перехрестя вулиць Велика Бердичівська - Шевченка.

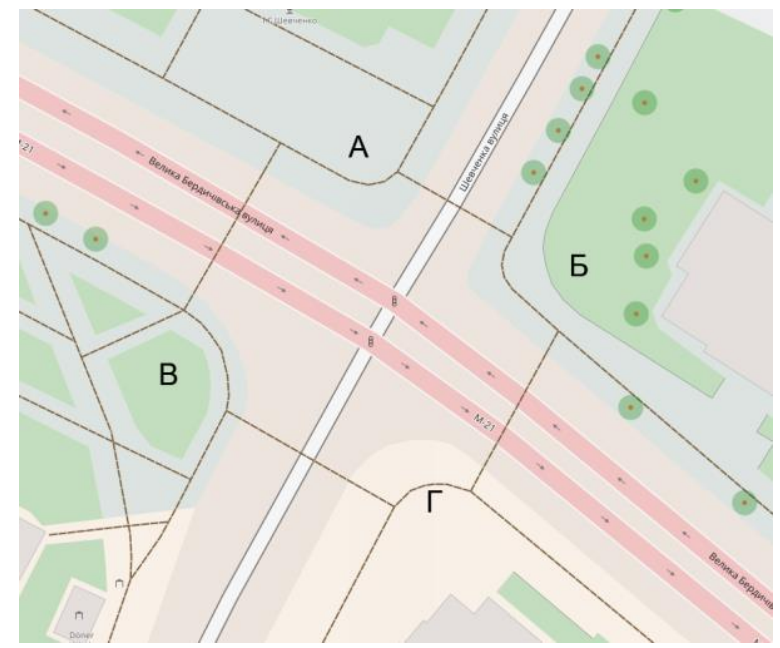

Рис. 9. Схема і загальний вигляд перехрестя вул. Велика Бердичівська-Шевченка

Для перехрестя (рис. 9) характерний інтенсивний рух міського та легкового транспорту, але заборонено рух вантажного транспорту, що є перевагою в зниженні шуму. Середній показник шуму на перехресті сягає 81,1 дБ. До ділянки А прилягає на невеликій відстані будівля, що обмежує простір розповсюдження звукових хвиль, розміщено незначну кількість зелених насаджень. На ділянці Б зафіксовано найвищий для цієї зони рівень шуму, спричинений обмеженням можливості розсіювання звукових хвиль.

Ділянці В характерні наявність будівлі навчального закладу, що прилягає, достатня кількість зелених насаджень, а також вільний від забудови простір, що пояснює найнижче значення показника акустичного забруднення в зоні цього перехрестя.

До ділянки Г на невеликій відстані прилягає житлова будівля, стіни якої мають засклені двері та вікна, а також тверду поверхню стін, що сприяе відбиванню звукових хвиль від будівлі, паркувальні місця, але відсутні зелені насадження.

Схему та загальний вигляд споруд, що прилягають до перехрестя вулиць Велика Бердичівська Довженка, зображено на рисунку 10.

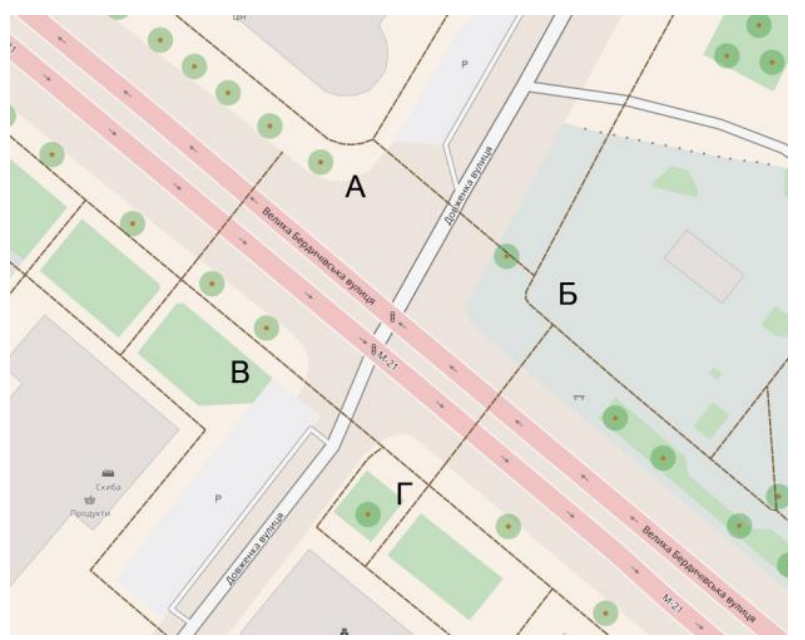

Рис. 10. Перехрестя вул. Велика Бердичівська - Довженка

На цьому перехресті на ділянках А, Б показник шуму найвищий і в середньому сягає 86,1 дБ, що $\epsilon$ зависоким значенням. До ділянки А (рис. 10) прилягає житлова будівля, різні торговельні структури, які знаходяться біля житлового будинку, зі скляними вікнами і дверима. До ділянки Б прилягає невеликий ринок, різні торговельні структури та житловий будинок, який знаходиться на невеликій відстані від проїзної частини. Високий показник шумності пояснюється заторами, причиною яких $є$ дорожні ремонтні роботи, та більшою шумністю двигунів при рушанні з місця з виїздом на зустрічну смугу. 
На ділянках В і Г рівень шуму найнижчий $(80,1$ дБ) в зоні цього перехрестя, що зумовлено на час проведення досліджень ремонтом дорожнього покриття на проїзній частині на перехресті. До цих ділянок прилягають житлові будинки, кількість зелених насаджень мінімальна. Рух вантажних автомобілів на цьому перехресті заборонено.

На рисунку 11 представлено схему та загальний вигляд споруд, що прилягають до перехрестя вулиць Велика Бердичівська - Гагаріна.

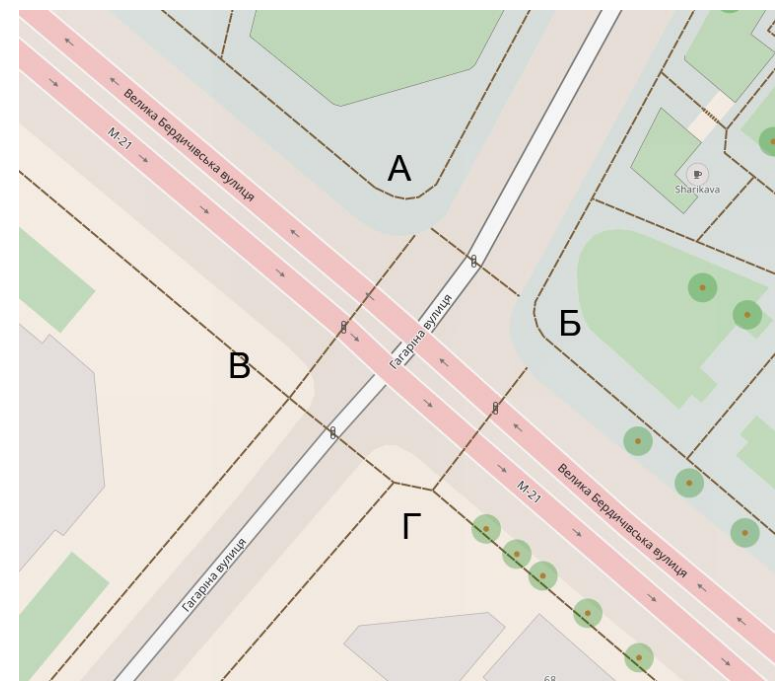

Рис. 11. Перехрестя вул. Велика Бердичівська - Гагаріна

На дорогах, що прилягають до цього перехрестя, рух вантажних автомобілів заборонено. На час проведення досліджень, незважаючи на сприятливі умови з точки зору мінімізації шумового забруднення (віддаленість будівель, наявність зелених насаджень) на ділянках А, Б (рис. 11), показники шуму найвищі (в середньому показник становить 88,6 дБ). Такий показник можна пояснити проведенням 3 боку ділянки Г на час досліджень ремонту дорожнього покриття і пов'язаною із цим зміною схеми руху через перехрестя, що зокрема передбачала виїзд на зустрічну смугу.

До ділянок В, Г прилягають житлові будинки і невелика торговельна структура, але кількість зелених насаджень мінімальна. В середньому на ділянках рівень шуму дорівнює 77,1 дБ.

На рисунку 12 зазначено схему та загальний вигляд споруд, що прилягають до перехрестя вулиць Льва Толстого - Велика Бердичівська - Жуйка.

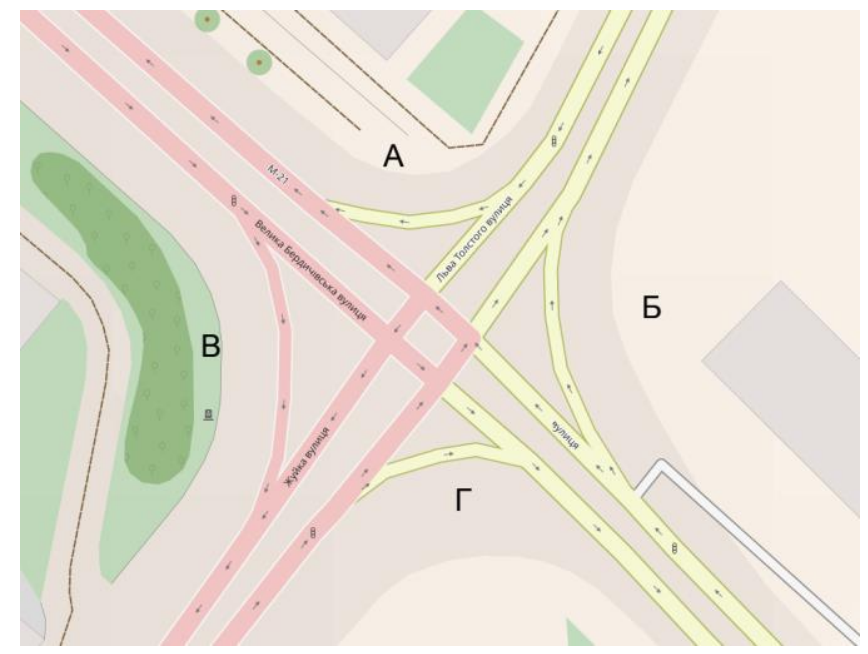

Рис. 12. Перехрестя вулиць Льва Толстого - Велика Бердичівська - Жуйка

Розглянуте перехрестя (рис. 12) суттєво відрізняється від розглянутих раніше, оскільки воно розташоване на виїзді з міста в бік міста Бердичева і на трьох із чотирьох під’їзих доріг (крім тієї, що веде із центру міста) дозволено рух всіх видів автотранспортних засобів. Крім того, в межах програми «Безпечне місто» на цьому перехресті (як і на перехресті із вул. Театральною) встановлено камери 
відеоспостереження, що дозволило отримати в онлайн-режимі інформацію про рух транспортних засобів через перехрестя (рис. 13) при одночасному вимірюванні рівня шумового забруднення.

Середній показник рівня шуму на перехресті становить 80,6 дБ при кількості смуг руху від 4 до 6 і за наявності руху великогабаритних транспортних засобів. До ділянок А, Б (рис. 13) безпосередньо прилягають житлові будинки, кількість зелених насаджень мінімальна. До ділянки В прилягає територія міської лікарні, на якій рівень шуму не має перевищувати 50 дБ, але на перехресті цей показник перевищено.

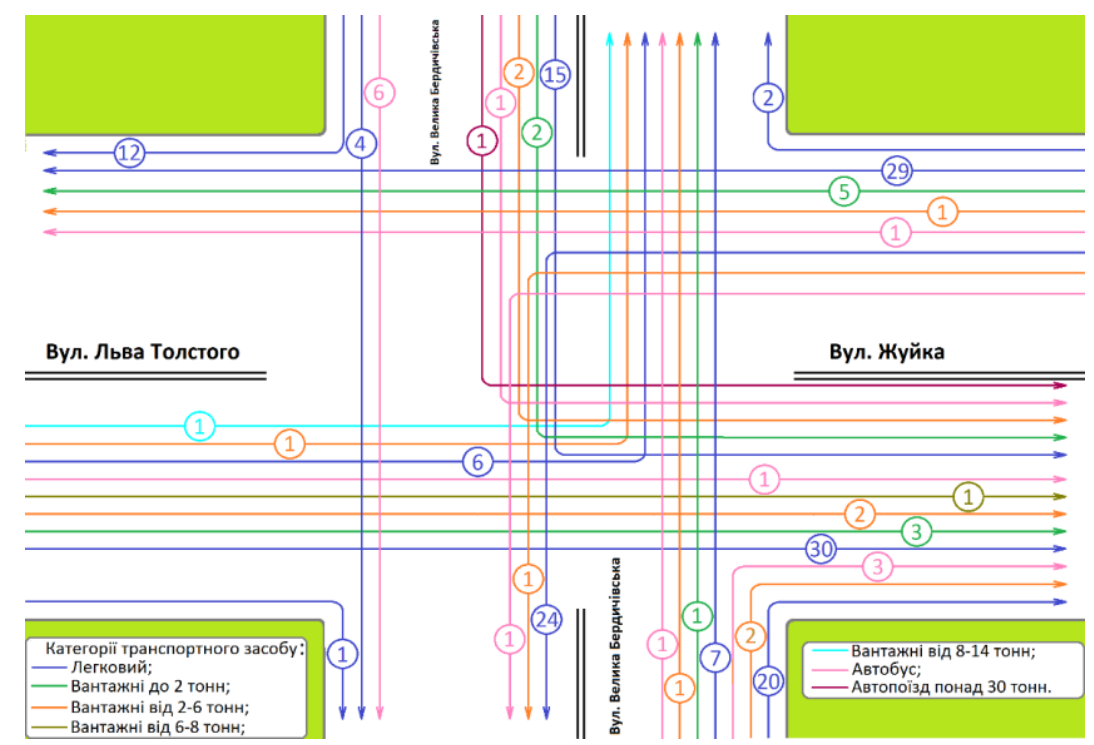

Рис. 13. Схема потоку транспортних засобів на перехресті вулиць Льва Толстого - Велика Бердичівська - Жуйка

Результат виміру шуму, що надходить на перехрестях з боку вул. Великої Бердичівської на всій ії протяжності зазначено в діаграмі (рис. 14).

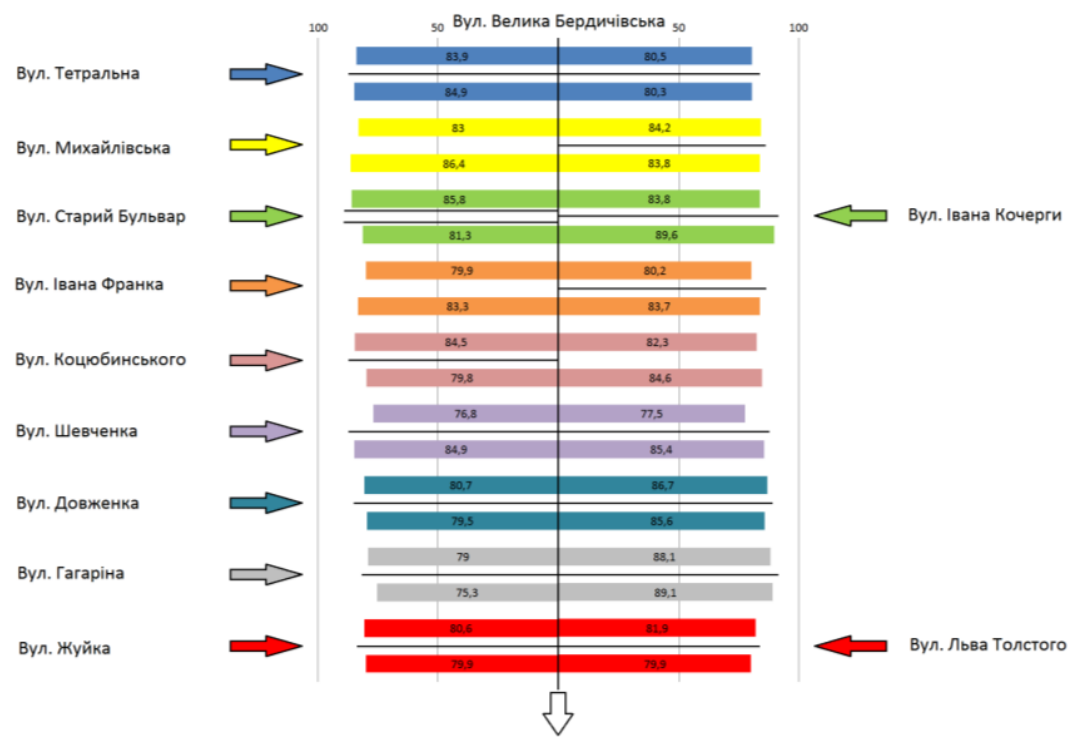

Рис. 14. Чисельні показники рівня шуму на перехрестях вздовж вул. Великої Бердичівської, дБ

Під час виконання замірів рівня шумового забруднення на перехрестях вул. Великої Бердичівської визначено також цей показник окремо від транспортних засобів, що рухалися через перехрестя по вулицях, що перетинають вул. Велику Бердичівську. Результати цих досліджень наведено на рисунку 15. 


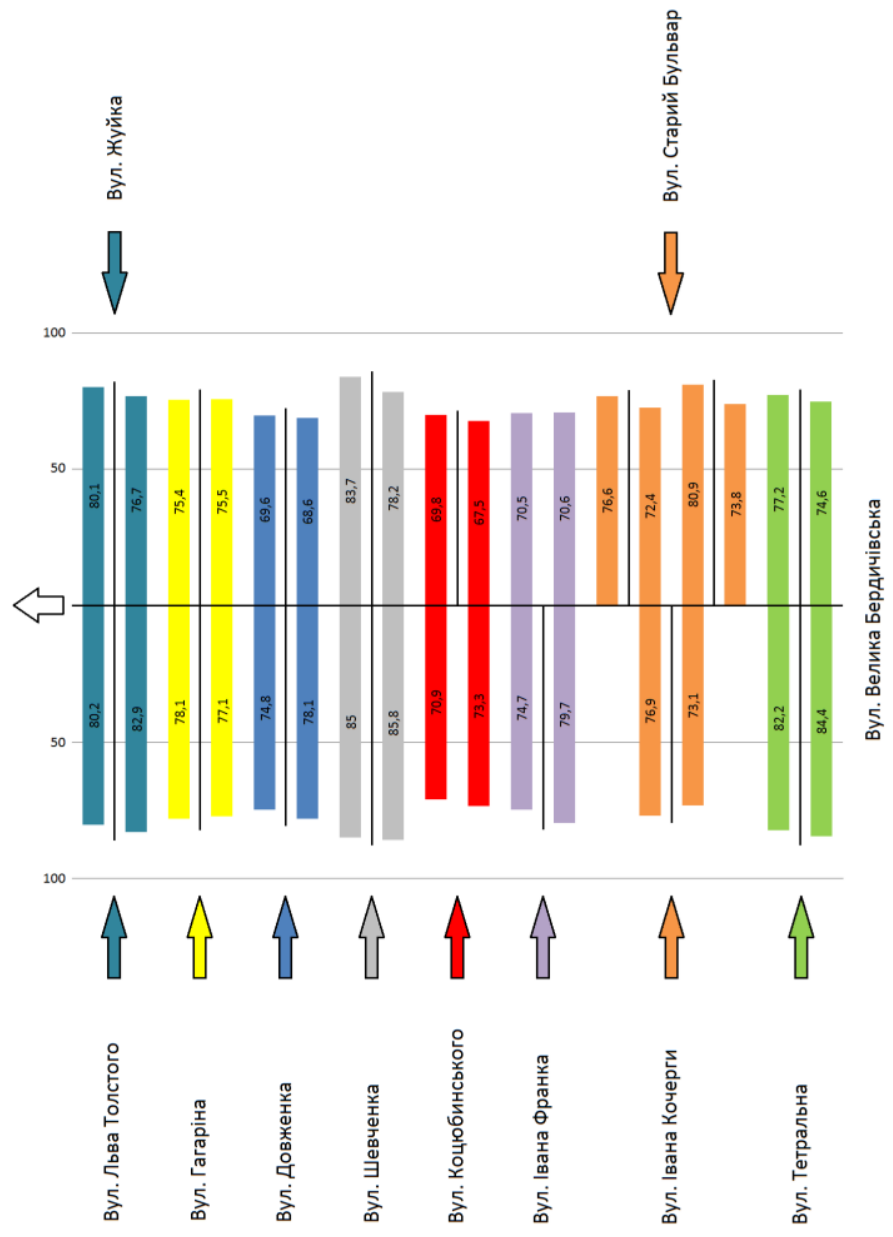

Рис. 15. Чисельні показники рівня шуму на перехресті поперечних вул. Великої Бердичівської, дБ

Висновки та перспективи подальших досліджень. У результаті досліджень шумового забруднення територій, що прилягають до перехресть вул. Великої Бердичівської міста Житомира, визначено, що в години пікових значень транспортних потоків практично на всіх перехрестях рівень шуму перевищує допустимі значення. Водночас дорожні ремонтні роботи поблизу перехресть із вул. Довженка і вул. Гагаріна внесли свої корективи в цей показник у бік збільшення, тому необхідні додаткові дослідження після завершення цих робіт. У межах подальших досліджень слід більш детально розглянути питання про вплив на рівень шумового забруднення таких факторів: відстань будівель від проїзної частини, форми та матеріали їх зовнішніх оздоблень: наявність, щільність і види зелених насаджень; синхронність роботи світлофорів, що дозволяють рух одночасно з кількох напрямків, та можливість зсуву в часі включення сигналу, що дозволяє рух; інтенсивність руху та ін. Результати можуть бути враховані при розробці заходів із оптимізації схем і режимів руху по дорогах міста Житомира та інших міст України з подібними схемами планування доріг і близькими загальними площами розміщення, кількістю мешканців та кількісними і якісними показниками рухомого складу.

Список використаної літератури:

1. Величко О.М. Контроль забруднення довкілля : навчальний посібник / О.М. Величко. - К. : Основа, 2002. -255 с.

2. Кучерявий В.П. Урбоекологія : підручник / В.П. Кучерявий. - Львів : Світ, 2002. - 439 с.

3. Білокур І.П. Акустичний контроль / І.П. Білокур. - Київ : ІЗМН, 1997. - 244 с.

4. Пукало М. Вплив шуму автомобільного транспорту на стан екології та методи зниження їх показників / М.Пукало, А.Наконечний, К.Ідрісов // Матеріали I науково-практичної онлайн-конференції ; відп. ред. канд. філос. наук М.Брегін. - Львів, 2016. - С. 32-38.

5. Коваленко Л.О. Визначення рівнів шуму на магістралях та вулицях міста / Л.О. Коваленко // Міжвузівський збірник «Наукові нотатки». - 2014. - Вип. № 46. - С. 252-256.

6. Стольберг Ф. Экология города : учеб. / Ф.Стольберг. - К. : Либра, 2000. - 464 с.

7. Янковська Л.В. Урбоекологія : навчальний посібник / Л.В. Янковська. - Тернопіль : РВВ ТНПУ, 2016. - 154 с.

8. Закон України «Про забезпечення санітарного та епідемічного благополуччя населення» / Відомості Верховної Ради України. - 1994.

9. Залеський I.I. Екологія людини : підручник / I.I. Залеський, М.О. Клименко. - К. : Академія, 2005. - 288 с. 
10. Допустимі рівні звуку (шуму) / Екологія. Право. Людина [Електронний ресурс].- Режим доступу : http://epl.org.ua/human-posts/dopustymi-rivni-zvuku-shumu/.

11. У Житомирі за 13 адресами виявили перевищення рівня шуму [Електронний ресурс]. - Режим доступу : https://www.zhitomir.info/news_181762.html.

12. Дослідження шумового забруднення на вулицях міста Львова, що створюється транспортом [Електронний pecypc]. - $\quad$ Режим доступу : http://ena.lp.edu.ua/bitstream/ntb/43583/2/2018_Boikiv_MInvestigation_of_noise_pollution_172-174.pdf.

13. Акустичне забруднення селітебного середовища міста від транспортних потоків [Електронний ресурс]. Режим доступу : http://www.kdu.edu.ua/statti/2007-5-1(46)/144.pdf.

\section{References:}

1. Velychko, O.M. (2002), Kontrol' zabrudnennja dovkillja, navchal'nyj posibnyk, Osnova, K., 255 p.

2. Kucherjavyj, V.P. (2002), Urboekologija, pidruchnyk, Svit, L'viv, 439 p.

3. Bilokur, I.P. (1997), Akustychnyj kontrol', IZMN, Kyi'v, 244 p.

4. Pukalo, M., Nakonechnyj, A. and Idrisov, K. (2016), «Vplyv shumu avtomobil'nogo transportu na stan ekologii' ta metody znyzhennja i'h pokaznykiv», Materialy I naukovo-praktychnoi' onlajn-konferencii', in Bregin, M. (ed.), L'viv, pp. 32-38.

5. Kovalenko, L.O. (2014), «Vyznachennja rivniv shumu na magistraljah ta vulycjah mista», Mizhvuzivs'kyj zbirnyk «Naukovi notatky», No. 46, pp. 252-256.

6. Stol'berg, F. (2000), Ekologiya goroda, ucheb., Libra, K., 464 p.

7. Jankovs'ka, L.V. (2016), Urboekologija, navchal'nyj posibnyk, RVV TNPU, Ternopil', 154 p.

8. VRU (1994), Zakon Ukrai'ny «Pro zabezpechennja sanitarnogo ta epidemichnogo blagopoluchchja naselennja».

9. Zales'kyj, I.I. and Klymenko, M.O. (2005), Ekologija ljudyny, pidruchnyk, Akademija, K., 288 p.

10. «Dopustymi rivni zvuku (shumu)», Ekologija. Pravo. Ljudyna, [Online], available at: http://epl.org.ua/humanposts/dopustymi-rivni-zvuku-shumu/

11. «U Zhytomyri za 13 adresamy vyjavyly perevyshhennja rivnja shumu», [Online], available at: https://www.zhitomir.info/news_181762.html

12. «Doslidzhennja shumovogo zabrudnennja na vulycjah mista L'vova, shho stvorjujet'sja transportom», [Online], available at: http://ena.lp.edu.ua/bitstream/ntb/43583/2/2018_Boikiv_M-Investigation_of_noise_pollution_172-174.pdf

13. «Akustychne zabrudnennja selitebnogo seredovyshha mista vid transportnyh potokiv», [Online], available at: http://www.kdu.edu.ua/statti/2007-5-1(46)/144.pdf

Опанасюк Євгеній Григорович - кандидат технічних наук, доцент кафедри автомобілів i транспортних технологій Державного університету «Житомирська політехніка».

http://orcid.org/0000-0003-3367-5816.

Наукові інтереси:

- прохідність автомобілів;

- експлуатаційні властивості автомобілів;

- перспективні методи дослідження надійності та експлуатаційних властивостей автомобілів.

E-mail: opanasyukevgen@gmail.com.

Бегерський Дмитро Богданович - кандидат технічних наук, доцент кафедри автомобілів i транспортних технологій Державного університету «Житомирська політехніка».

http://orcid.org/0000-0002-8357-0038.

Наукові інтереси:

- прохідність автомобілів;

- моделювання транспортних потоків;

- моделювання технологічних процесів автомобільного транспорту.

E-mail: begerskiy@gmail.com.

Можаровський Микола Мар'янович - старший викладач кафедри автомобілів і транспортних технологій Державного університету «Житомирська політехніка».

https://orcid.org/0000-0002-4720-3783.

Наукові інтереси:

- динаміка і міцність машин; експлуатаційні властивості автомобілів.

E-mail: mykolamozharovskyi@gmail.com.

Вітюк Іван Васильович - старший викладач кафедри автомобілів і транспортних технологій Державного університету «Житомирська політехніка».

http://orcid.org/0000-0002-3577-8758.

Наукові інтереси:

- транспортна логістика; експлуатаційні властивості автомобілів;

- сертифікація та ліцензування автомобільного транспорту.

E-mail: vnvik74@gmail.com. 